\title{
PENERAPAN PERMAINAN TEBAK KATA HIRAGANA DENGAN MENGGUNAKAN METODE TEAM GAMES TOURNAMENT (TGT) UNTUK MENINGKATKAN PENGUASAAN HURUF HIRAGANA DI KELAS X4 SMA LAB SINGARAJA
}

\author{
I Md Egi Yoga Iswara', K.E.K.Adnyani ${ }^{2}$, G. S. Hermawan \\ Jurusan Pendidikan Bahasa Jepang \\ e-mail: yogaiswara@gmail.com \\ krishna.adnyani@undiksha.ac.id satya.hermawan@undiksha.ac.id
}

\begin{abstract}
Abstrak
Penelitian ini bertujuan untuk (1) meningkatkan penguasaan huruf Hiragana untuk siswa kelas X4 SMA Lab Undiksha Singaraja melalui penerapan permainan tebak kata dengan menggunakan metode Team Games Tournament (TGT) (2) mendeskripsikan respons siswa kelas X4 SMA Lab Undiksha Singaraja terhadap penerapan permainan tebak kata dengan menggunakan metode Team Games Tournament (TGT). Subjek dalam penelitian ini adalah siswa kelas X4 SMA Lab Undiksha Singaraja tahun ajaran 2016/2017 sebanyak 27 orang siswa. Penelitian ini merupakan penelitian tindakan kelas yang dilaksanakan dalam dua siklus. Metode pengumpulan data yang digunakan adalah tes, kuesioner dan wawancara. Hasil penelitian menunjukkan bahwa penerapan permainan tebak kata dengan menggunakan metode team games tournament (TGT) dapat meningkatkan penguasaan huruf Hiragana siswa kelas X4. Peningkatan tersebut diketahui berdasarkan hasil penelitian, terjadi peningkatan ketuntasan klasikal dari pretest yaitu $0 \%$, kemudian meningkat menjadi $55,55 \%$ pada posttest siklus I, kemudian meningkat menjadi $88,88 \%$ pada posttest siklus II. Dari hasil analisis angket, siswa memberi respons positif terhadap penerapan permainan tebak kata dengan menggunakan metode team games tournament (TGT). Melalui penerapan permainan tebak kata dengan menggunakan metode team games tournament (TGT) siswa berpikir bahwa metode pembelajaran ini akan bermanfaat karena siswa merasa aktif dalam belajar dan meningkatkan penguasaan huruf Hiragana .
\end{abstract}

Kata kunci: kooperatif, TGT, tebak kata, Hiragana

\section{要旨}

本研究の目的は、（1）平仮名を推測今゙ームを使用するチーム。ダーム競争を用いた場合の 学習者の平仮名習熟の向上を知ること（2）どう学習法を使用した際の学習者の反応を明らかにする ことである。本研究の対象は2016年度ガネシャ教育大学付属高等学校 $1 O$ 年生 4 組の 27 名である。 本研究は 2 周期に渡る教室実践活動調查である。データはアンケート、テスト、インタビューにより 收集する。本研究の結果は平仮名を推測ゲームを使用したチームダームトーナメントは、学習者の平 仮名習熟を高められた。これは予備テストで標準を超えた割合はO％であったのに対し、第一周期終 了時のそれは 5 5，55\%に高められし、第二周期終了時のそれは８８８８％に上昇したことが分 かった。アンケートの分析の結果は学習者のこの学習法に対する反応は良好であった。本研究を通し て多くの学習者は、この学習法が役立つと考え、学習に積極的に参加し平仮名の理解が向上したと感 じている。

キーワード：グループ学習法、平仮名を推測ゲーム、チーム。ゲーム競争、平仮名 の理解。

\section{Pendahuluan}

Bahasa merupakan suatu kebutuhan primer yang dibutuhkan oleh manusia untuk melaksanakan segala kegiatannya untuk bergaul baik dalam lingkup nasional maupun internasional. Dalam bahasa terdapat 4 aspek utama yang ada di dalamnya. Aspek tersebut meliputi : menulis, membaca, mendengar, dan berbicara. Keempat aspek aspek tersebut saling berkaitan erat satu sama lainnya. Dengan menguasai keempat aspek berbahasa tersebut seorang manusia bisa dikatakan mampu berbahasa dengan baik dan benar serta mampu memberikan informasi yang benar ke lawan bicaranya. 
Dalam bahasa Jepang pun terdapat empat aspek kebahasaan di dalamnya yaitu menulis, membaca mendengarkan dan juga berbicara. Salah satu aspek bahasa yang perlu dipersiapkan dan dikembangkan pada pembelajar awal bahasa Jepang adalah kemampuan menulis. Kemampuan menulis merupakan kemampuan yang terlihat sederhana, namun kemampuan ini harus dikuasai oleh pembelajar karena pengenalan terhadap huruf termasuk modal awal memiliki keterampilan keterampilan berbahasa yang lain seperti keterampilan membaca.

Dalam bahasa Jepang dikenal berbagai macam bentuk huruf yang harus di pelajari diantaranya yaitu huruf hiragana, huruf katakana dan huruf kanji. Dari ketiga jenis huruf terebut huruf hiragana merupakan huruf yang paling awal dipelajari dan juga huruf yang harus dikenal oleh pembelajar awal bahasa Jepang. Dalam mempelajari huruf hiragana inipun merupakan sesuatu yang susah untuk dipelajari karena pelajar pemula pasti akan mengalami kesulitan dalam mengingat bentuk dari huruf hiragana tersebut, urutan goresannya dan juga cara bacanya.

Hal ini merupakan salah satu hambatan bagi pembelajar bahasa Jepang pemula sehingga pembelajar sering menggunakan huruf romawi dalam pembelajaran sehari hari. Di sisi lain, kesalahan dalam penulisan huruf hiragana bisa berakibat fatal. Hal ini disebabkan tulisan dengan urutan yang salah akan menghasilkan bentuk yang berbeda sehingga akan sulit terbaca. Namun dengan menggunakan metode atau teknik yang tepat, belajar bahasa Jepang dalam hal ini menulis huruf hiragana pasti akan lebih menyenangkan bagi pembelajar awal bahasa Jepang dan mampu mengatasi permasalahan yang sering muncul dalam belajar huruf hiragana.

Salah satu teknik yang sering digunakan dalam pembelajaran adalah memberikan permainan di dalam proses pembelajaran. Dengan menyisipkan aktivitas bermain dalam proses pembelajaran suasana pembelajaran akan dan dapat membuat siswa ikut serta dalam proses pembelajaran tersebut. Dari berbagai macam jenis permainan yang ada salah satu permainan yang mampu membantu siswa untuk mempelajari huruf hiragana lebih mendalam lagi yaitu dengan menerapkan permainan tebak kata hiragana dengan menggunakan metode Team Games Tournament (TGT).

Menerapkan permainan tebak kata hiragana dengan menggunakan metode Team Games Tournament (TGT) merupakan suatu cara yang tepat untuk digunakan, karena siswa akan dibentuk menjadi beberapa kelompok yang heterogen dan akan bersaing dengan tim yang lainnya untuk menjadi yang terbaik. Dengan menggunakan permainan ini siswa akan memiliki sifat kompetitif untuk mejadi yang terbaik di kelas tersebut.

Siswa di kelas X4 SMA Lab Undiksha Singaraja merupakan siswa yang tergolong cukup pandai diantara kelas $X$ yang lainnya. Namun di dalam pelajaran bahasa Jepang siswa kelas X4 masih tergolong kurang. Setelah melakukan observasi dengan memberikan pretest dikelas X4 dapat diketahui bahwa siswa siswi kelas X4 mendapatkan hasil dari tes terkait kemampuan siswa menulis huruf hiragana tergolong rendah, ini dibuktikan dengan nilai rata rata yang diperoleh dari pelaksanaan tes awal adalah 39,1 dari 27 orang siswa yang diberi tes. Dari hasil tersebut tidak ada siswa memperoleh nilai di atas standar kriteria ketuntasan minimal (KKM) yaitu 78 yang ditetapkan oleh sekolah. Berdasarkan hasil tes awal tersebut nilai terendah yang didapatkan oleh siswa yaitu 20 dan nilai tertingi yang didapatkan oleh siswa yaitu 73,3.

Setelah melakukan wawancara terhadap 6 orang siswa diketahui bahwa alasan yang mendasari terjadiya masalah siswa kelas $\mathrm{X} 4$ belum bisa menulis huruf hiragana yaitu bentuk huruf hiragana yang membingungkan dan cara penulisanya yang susah. Selain itu siswa kelas X4 merasakan bahwa cara mengajar yang dilakukan selama ini kurang menarik bagi mereka dan cenderung membosankan. Mereka berharap bahwa selama proses pembelajaran bahasa Jepang suasana yang ada lebih menyenangkan dan berisi permainan di dalam proses pembelajaran bahasa Jepang.

Berdasarkan hal tersebut diadakan Penelitian Tindakan Kelas (PTK) dengan menguji coba permainan tebak kata hiragana dengan menggunakan metode Team Games Tournament (TGT). Hasil penelitian ini akan dijadikan bahan skripsi yang berjudul : Penerapan Permainan Tebak Kata Hiragana Dengan Menggunakan Metode Team Games 
Tournament (TGT) Untuk Meningkatkan Penguasaan Huruf Hiragana Di Kelas X4 SMA Lab Singaraja. Berdasarkan latar belakang masalah yang telah dikemukakan di atas maka rumusan masalah dalam penelitian ini adalah : Apakah penerapan permainan tebak kata hiragana dengan menggunakan metode team games tournament (TGT) dapat meningkatkan penguasaan huruf hiragana untuk siswa kelas X4 SMA Lab Undiksha Singaraja dan bagaimana respons siswa terhadap penerapan permainan tebak kata hiragana dengan menggunakan metode Team Games Tournament (TGT).

Adapun tujuan penelitian ini adalah Untuk mengetahui sejauh mana penerapan permainan tebak kata hiragana dengan menggunakan metode Team Games Tournament (TGT) dapat meningkatkan penguasaan huruf hiragana untuk siswa kelas X4 SMA Lab Undiksha Singaraja dan untuk mengetahui respons siswa kelas X4 SMA Lab Undiksha Singaraja terhadap penerapan permainan tebak kata hiragana dengan menggunakan metode Team Games Tournament (TGT).

Dalam upaya pencapaian tujuan pembelajaran yang diharapkan, maka proses belajar mengajar siswa diharapkan mempunyai aktivitas belajar yang positif dan menyenangkan. Menurut Usman, (dalam Hamid, 2011: 207), pembelajaran merupakan sebuah proses yang mengandung serangkaian perbuatan guru dan siswa atas dasar hubungan timbal balik, yang berlangsung dalam situasi edukatif untuk tercapai tujuan tertentu. Sedangkan menurut Jogiyanto (2006: 12), pembelajaran terjadi ketika terdapat perubahan karena suatu kejadian dan perubahan yang terjadi bukan karena perubahan secara alami atau karena menjadi dewasa yang dapat terjadi dengan sendirinya atau karena perubahannya sementara saja, tetapi lebih karena reaksi dari situasi yang dihadapi.

Salah satu cara agar proses pembelajaran menjadi lebih positif dan menyenangkan maka dapat diterapkan pembelajaran kooperatif dalam suatu proses pembelajaran. Eggen dan Kauchak (dalam Trianto, 2011: 58) mendefinisikan bahwa pembelajaran kooperatif merupakan sebuah kelompok strategi pengajaran yang melibatkan siswa bekerja secara berkolaborasi untuk mencapai tujuan bersama. Pembelajaran kooperatif disusun dalam sebuah usaha untuk meningkatkan partisipasi siswa, memfasilitasi siswa dengan pengalaman sikap kepemimpinan dan membuat keputusan dalam kelompok, serta memberikan kesempatan pada siswa untuk berinteraksi dan belajar bersama-sama siswa yang berbeda latar belakangnya sehingga membuat proses pembelajaran menjadi lebih menarik.

Pembelajaran kooperatif dikenal dengan pembelajaran secara kelompok. Tapi belajar kooperatif lebih dari sekedar belajar kelompok atau kerja kelompok karena dalam belajar kooperatif ada struktur dorongan atau tugas yang bersifat kooperatif sehingga memungkinkan terjadinya interaksi secara terbuka dan hubungan yang bersifat interdepedensi efektif di antara anggota kelompok (Taniredja, dkk. 2011: 55-56).

Model pembelajaran kooperatif ada berbagai macam dan salah satunya yaitu model pembelajaran kooperatif tipe TGT (Teams Games Tournament). Model ini pada mulanya dikembangkan oleh David DeVries dan Keith Edwards (Slavin. 2010:13). Model Pembelajaran Teams Games Tournament (TGT) adalah salah satu tipe pembelajaran kooperatif yang menempatkan siswa dalam kelompok kelompok belajar yang beranggotakan 4 sampai 6 orang siswa yang memiliki kemampuan, jenis kelamin dan suku atau ras yang berbeda. Dalam Teams Games Tournament (TGT), permainan ini berupa pertanyaan pertanyaan yang ditulis pada kartu kartu yang diberi angka. Pertanyaan pertanyaan yang dimaksud adalah pertanyaan pertanyan yang relevan dengan materi pelajaran yang dirancang untuk mengetes kemampuan siswa dari penyampaian pelajaran kepada siswa di kelas. Setiap wakil kelompok akan mengambil sebuah kartu yang diberi angka dan berusaha untuk menjawab pertanyaan yang sesuai tersebut. Permainan ini dimainkan pada meja meja turnamen. Dalam model ini siswa setelah belajar dalam kelompoknya masing masing, anggota kelompok yang setingkat kemampuannya akan dipertemukan dalam suatu pertandingan/turnamen yang dikenal dengan "tournaments" yang diadakan tiap akhir unit pokok bahasan atau akhir pekan.

Selain TGT (Team Games Tournament) terdapat juga metode lain dalam pembelajaran kooperatif yaitu metode tebak kata. Tebak kata merupakan salah satu 
permainan yang sering ditemukan pada acara atau tayangan kuis di televisi, permainan ini sangat menyenangkan dan juga berguna dalam pembelajaran. Dalam pembelajaran kooperatif terdapat berbagai macam metode pembelajaran, salah satunya adalah tebak kata. Cara kerja metode ini mengandalkan pengetahuan dasar yang dimiliki oleh siswa. Pembelajaran menggunakan metode tebak kata dapat dilakukan dengan berbagai cara, metode tebak kata memiliki banyak modifikasi dan aplikasi yang beragam dan menyenangkan. Dari model serempak, kelompok, berpasangan, sampai dengan sendiri sendiri. Meskipun cara kerjanya sama, tetapi penerapan masing-masing berbeda (Muliawan. 2016:223).

\section{Metode}

Pada penelitian ini merupakan penelitian kualitatif. Penelitian kualitatif berusaha mengungkapkan gejala secara menyeluruh dan sesuai dengan konteks (holistik kontekstual) melalui pengumpulan data dari latar alami dengan memanfaatkan diri peneliti sebagai instrumen kunci. Penelitian semacam ini bersifat deskriptif kualitatif dan cenderung menggunakan analisis dengan pendekatan induktif. Proses dan makna dari sudut pandang subjek dengan kejelasan perspektifnya lebih ditonjolkan dalam penelitian ini sehingga konsep, teori, dan model penelitian kualitatif dapat memosisikan penelitiannya. Ciri ciri penelitian kualitatif disusun dalam bentuk narasi wacana yang bersifat kreatif dan mendalam serta menunjukkan ciri ciri alamiah atau fenomenanya. Konstruksi narasi wacana sangat diharapkan dilaporkan dalam bentuk gambar, tabel, bagan, dan hasil analisis dari fakta lapangan, diperkuat oleh data pustaka atau dokumen otentik.

Jenis penelitian pada pada penelitian ini yaitu jenis penelitian tindakan kelas (PTK). Penelitian tindakan kelas merupakan suatu bentuk kajian yang bersifat reflektif, yang dilakukan oleh pelaku tindakan untuk meningkatkan kemantapan rasional dari tindakan tindakannya dalam melaksanakan tugas dan memperdalam pemahaman terhadap kondisi dalam pembelajaran (Hopkins, 1993).

Lokasi penelitian yang dipilih adalah kelas X4 SMA Lab Undiksha Singaraja yang beralamat di jalan Jatayu no 10 Singaraja kelurahan Kaliuntu Kecamatan Buleleng Kabupaten Buleleng. Waktu pelaksanaan penelitian ini yaitu pada semester ganjil tahun ajaran 2016/2017.

Subjek penelitian merupakan orang atau sesuatu yang memberikan informasi dalam suatu penelitian. Dalam penelitian ini yang menjadi subjek penelitian adalah siswa kelas X4 SMA Lab Undiksha Singaraja yang memperoleh mata pelajaran bahasa Jepang sebanyak 27 orang siswa. Hal yang mendasari pemilihan subjek penelitian ini karena kurangnya penguasaan huruf Hiragana oleh siswa kelas X4 tersebut.

Objek penelitian dapat dibedakan menjadi 2 macam, yaitu objek yang mencerminkan proses dan objek yang mencerminkan produk (Wendra, 2012:54). Objek yang mencerminkan proses meliputi tindakan yang dilakukan dan materi yang digunakan. Pada penelitian ini objek yang mencerminkan proses adalah aktivitas dan respons siswa dalam Penerapan Permainan Tebak Kata Hiragana dengan Menggunakan Metode Team Games Tournament (TGT). Sedangkan objek yang mencerminkan produk meliputi hal yang diinginkan mengalami perbaikan. Pada penelitian ini hal yang ingin diperbaiki adalah penguasaan huruf Hiragana siswa kelas X4.

Wendra (2009:54) menyatakan bahwa prosedur penelitian menguraikan tentang prosedur kegiatan penelitian yang menggunakan siklus. Penelitian ini dilaksanakan dengan beberapa siklus sampai ditemukan tindakan yang terbaik. Penelitian ini merupakan penelitian tindakan kelas (PTK) yang mempergunakan beberapa siklus pada pelaksanaannya. Penelitian ini dilakukan sebanyak dua siklus yang di setiap siklusnya terdapat dua kali pertemuan. Pada setiap siklus terdapat prosedur penelitian yang dilaksanakan. Berikut merupakan rincian prosedur penelitian.

a. Perencanaan

Pada tahap perencanaan, sejalan dengan penelitian tindakan kelas maka tahap perencanaan dalam penelitian ini adalah sebagai berikut : 
1. Peneliti menganalisis silabus untuk menyesuaikan pokok bahasan agar sesuai dengan tujuan pembelajaran yang dikembangkan berdasarkan waktu yang tersedia.

2. Menyusun rencana pelaksanaan pembelajaran (RPP) yang sesuai dengan permainan ulara tangga untuk meningkatkan penguasaan kosakata bahasa Jepang.

3. Menyiapkan media permainan tebak kata

4. Peneliti menyusun format evaluasi yaitu tes yang berupa pretes dan posttest terkait kosakata yang telah dipelajari

5. Peneliti menyusun format angket/kuesioner untuk mengetahui respons siswa tentang penerapan permainan tebak kata dalam proses pembelajaran

\section{b. Pelaksanaan}

Tahap selanjutnya adalah tahap pelaksanaan. Pada tahap ini guru melaksanakan kegiatan belajar mengajar dengan menggunakan RPP, media ataupun alat yang disiapkan pada tahap perencanaan. Jadi, tahap pelaksanaan merupakan implementasi dari tahap perencanaan. Pada tahap pelaksanaan dilakukan program pembelajaran, pengambilan atau pengumpulan data lembar observasi, hasil tes dan hasil angket.

c. Pengamatan dan Evaluasi

Selama pelaksanaan tindakan berlangsung pengamatan merupakan hal yang diteliti secara seksama terhadap siswa saat belajar agar dapat mengetahui respons yang terjadi pada siswa. Selama pelaksanaan tindakan berlangsung, dilaksanakan evaluasi untuk mengetahui apakah tahap pelaksanaan sudah sesuai dengan tahap perencanaan yang telah ditetapkan dan untuk mengetahui apakah terjadi peningkatan kemampuan penguasaan penggunaan huruf Hiragana oleh siswa.

Tujuan pelaksanaan evaluasi adalah untuk mendapatkan data yang akurat mengenai pelaksanaan tindakan dan mengetahui keberhasilan pelaksanaan tindakan. Evaluasi dilakukan setelah pelaksanaan tindakan berakhir. Hal ini untuk mendapat data tentang pelaksanaan kegiatan pembelajaran yang telah dilaksanakan.

d. Refleksi

Pada bagian ini hasil pengamatan dan evaluasi direfleksikan tingkat ketercapaiannya, baik yang terkait dengan proses maupun hasil tindakan. Refleksi bertujuan untuk mengetahui kekuatan kekuatan yang ditemukan, kelemahan kelemahan, dan hambatan yang mengganjal upaya dalam pencapaian tujuan secara optimal dan respons siswa (Wendra, 2012:56). Dari hasil refleksi ini digunakan untuk menentukan tindakan siklus selanjutnya. Tindakan positif yang berkonstribusi terhadap hasiltetap dipertahankan pada siklus berikutnya. Sedangkan tindakan yang negatif dan menghambat kemudian direvisi atau dimodifikasi untuk dapat mendukung siklus selanjutnya.

Dalam penelitian ini, ada beberapa teknik pengumpulan data yang digunakan. Teknik pengumpulan data dalam penelitian ini adalah sebagai berikut.

1. Instrumen Tes

Tes dapat didefinisikan sebagai suatu pernyataan atau tugas atau seperangkat tugas yang direncanakan untuk memperoleh informasi tentang trait (sifat) atau atribut pendidikan atau psikologik yang setiap butir pertanyaan atau tugas tersebut mempunyai jawaban atau ketentuan yang dianggap benar.

Pada penelitian ini dalam mengumpulkan data, tes yang diberikan berupa pretest dan posttest. Pretest merupakan tes yang dilakukan pada awal proses penelitian untuk mengetahui seberapa besar siswa kelas X4 menguasai huruf hiragana yang dilakukan hanya 1 kali pada pertemuan pertama sebelum penerapan permainan tebak kata dengan menggunakan metode team games tournament dilaksanakan. Sedangkan soal posttest merupakan soal yang diberikan kepada seluruh siswa kelas X4 untuk mengetahui sejauh mana pemahaman siswa setelah diadakannya penerapan permainan tebak kata dengan menggunakan metode team games tournament yang dilakukan sebanyak 2 kali pada pertemuan kedua di setiap siklus yang dilaksanakan.

Pretest dan posttest yang dijawab oleh siswa kelas X4 merupakan jenis tes esai yang berisikan 15 butir soal dimana dalam soal pretest maupun postest berisiskan soal untuk mengetahui kemampuan siswa dalam membaca huruf hiragana, menulis huruf hiragana, dan mengingat goresan dari huruf hiragana. 


\section{Kuesioner}

Kuesioner adalah suatu teknik pengumpulan informasi yang memungkinkan analis mempelajari sikap sikap, keyakinan, perilaku, dan karakteristik beberapa orang utama di dalam organisasi yang bisa terpengaruh oleh sistem yang diajukan atau oleh sistem yang sudah ada. Dengan menggunakan kuesioner, analis berupaya mengukur apa yang ditemukan dalam wawancara, selain itu juga untuk menentukan seberapa luas atau terbatasnya sentimen yang diekspresikan dalam suatu wawancara.

Kuesioner yang digunakan pada penelitian ini menggunakan kuesioner jenis tertutup dan terbuka. Kuesioner tertutup dan terbuka ini diisi oleh seluruh siswa kelas X4 untuk mengetahui respons mereka mengenai penerapan permainan tebak kata dengan menggunakan metode team games tournament yang dilakukan dikelas X4. Dalam kuesioner tertutup terdapat 7 buah pertanyaan yang harus diisi siswa dengan memberikan tanda centang pada kolom jawaban sangat setuju, setuju, cukup setuju, kurang setuju dan sangat tidak setuju. Pada kuesioner terbuka terdapat 2 pertanyaan mengenai respons siswa kelas X4 yang harus diisi jawaban berupa kalimat kalimat untuk menjawab pertanyaan yang ada di dalam kuesioner terbuka. Kuesioner tertutup maupun terbuka diberikan kepada siswa kelas X4 disetiap akhir siklus dilaksanakan.

\section{Wawancara}

Wawancara adalah merupakan pertemuan dua orang untuk bertukar informasi dan ide melalui tanya jawab, sehingga dapat dikonstruksikan makna dalam suatu topik tertentu, dan wawancara dibagi tiga yaitu: wawancara terstruktur/structured interview, semi terstruktur /semistructure interview, dan tidak terstruktur /unstructured interview (Sugiyono, 2010: 317319). Wawancara dalam penelitian ini menggunakan wawancara terstruktur yaitu wawancara yang dimana peneliti menggunakan pedoman wawancara yang digunakan dan hanya berupa garis garis besar permasalahan yang akan ditanyakan (Sugiyono, 2010: 320).

Wawancara terstruktur sering digunakan dalam penelitian pendahuluan atau untuk penelitian yang lebih mendalam tentang subyek yang diteliti. Pada penelitian pendahuluan, peneliti berusaha mendapatkan informasi awal tentang berbagai isu atau permasalahan yang ada pada obyek, peneliti dapat menentukan secara pasti permasalahan atau variabel apa yang harus diteliti. Wawancara pada penelitian ini ditujukan kepada 6 orang siswa kelas X4 diakhir setiap pertemuan pada tiap siklusnya. Wawancara yang dilakukan kepada siswa kelas X4 ditunjukan pada siswa secara acak.

Data hasil belajar siswa berupa hasil tes yang sudah diperoleh akan dianalisa menggunakan teknik deskriptif kuantitatif. Dalam pengolahan data ini diganakan sistem skala seratus seperti diuraikan dalam tabel berikut ini.

Tabel 1 Tabel Hasil Belajar Siswa (Nurkancana \& Sunartana: 1986)

Nurkancana \& Sunartana (1986)

\begin{tabular}{|l|l|l|l|}
\hline No & \multicolumn{1}{|c|}{$\begin{array}{c}\text { Rentang } \\
\text { nilai }\end{array}$} & Nilai & Kategori mutu \\
\hline 1 & $100-86$ & A & Sangat Tinggi \\
\hline 2 & $85-76$ & B & Tinggi \\
\hline 3 & $75-60$ & C & Sedang \\
\hline 4 & $59-40$ & D & Rendah \\
\hline 5 & $39-0$ & E & $\begin{array}{l}\text { Sangat } \\
\text { Rendah }\end{array}$ \\
\hline
\end{tabular}

Sejalan dengan pedoman di atas secara individu siswa dikatakan tuntas dalam pembelajaran huruf hiragana apabila skor yang diperoleh minimal 78. Secara klasikal, pembelajaran dikatakan tuntas jika $78 \%$ siswa yang ada di kelas itu memperoleh skor minimal 78, sehingga tindakan dapat dihentikan. Sebaliknya, jika jumlah siswa yang memperoleh nilai 78 kurang dari $78 \%$ tindakan perlu dimodifikasi sampai memperoleh skor yang diharapkan. Untuk menentukan ketuntasan individu gunakan rumus sebagai berikut.

Ketuntasan individu $=$ skor yang diperoleh siswa $\times 100$ : skor maksimal 
Untuk menentukan persentase siswa yang sudah mencapai ketuntasan dalam belajar, dapat diketahui dengan menggunakan rumus sebagai berikut.

Ketuntasan klasikal = jumlah siswa yang memperoleh nilai $\geq 78 \times 100$ : jumlah seluruh siswa

(Nurkancana dan Sunartana, 1992)

Hasil dari angket yang jawaban siswa mengenai respon terhadap permainan tebak huruf diintepretasikan dengan menggunakan rumus untuk mengolah hasil kuesioner yang nantinya dikerjakan oleh subjek penelitian. Adapun rumus yang digunakan untuk mengolah data angka sebagai berikut.

Tabel 2 Tabel Kriteria Angket Siswa

\begin{tabular}{|l|l|l|}
\hline No & Kriteria kualitas & Kategori \\
\hline 1 & $\mathrm{X} \geq \mathrm{Mi}+1,5 \mathrm{Sdi}$ & Sangat positif \\
\hline 2 & $\mathrm{Mi}+0,5 \mathrm{Sdi} \leq \mathrm{x}<\mathrm{Mi}+1,5 \mathrm{Sdi}$ & Positif \\
\hline 3 & $\mathrm{Mi}-1,5 \mathrm{Sdi} \leq \mathrm{x} \mathrm{Mi}+0,5 \mathrm{Sdi}$ & Cukup positif \\
\hline 4 & $\mathrm{Mi}-1,5 \mathrm{Sdi} \leq \mathrm{x}<\mathrm{Mi}-0,5 \mathrm{Sdi}$ & Kurang positif \\
\hline 5 & $\mathrm{X}<\mathrm{Mi}-1,5 \mathrm{Sdi}$ & Sangat kurang positif \\
\hline
\end{tabular}

Keterangan

$\mathrm{Mi}$ : mean ideal (nilai rata rata)

Mean adalah jumlah dari keseluruhan angka yang ada, dibagi dengan banyaknya angka tersebut

Sdi : standar deviasi ideal

Deviasi merupakan selisih atau simpangan dari masing masing skor atau interval, dari nilai rata rata hitungnya.

Standar deviasi adalah selisih rata rata yang telah menempuh proses perhitungan yang berfungsi menutup dan menstandarisasikan nilai positif atau negatif dalam perhitungan mean deviasi sehingga memiliki kadar kepercayaan atau reliabilitas yang lebih mantap.

Mi diperoleh dengan menggunakan rumus sebagai berikut

Sdi diperoleh dengan menggunakan rumus sebagai berikut

Berdasarkan perhitungan tersebut, hasil yang diperoleh dapat dikonversikan berdasarkan pedoman berikut.

Tabel 3 : Penggolongan Respons Angket Siswa

\begin{tabular}{|l|l|l|}
\hline No & Skor & Kategori \\
\hline 1 & $\mathrm{X} \geq 45$ & Sangat positif \\
\hline 2 & $\begin{array}{l}35 \leq \mathrm{X}< \\
45\end{array}$ & Positif \\
\hline 3 & $\begin{array}{l}25 \leq \mathrm{X} \\
<35\end{array}$ & Cukup positif \\
\hline 4 & $\begin{array}{l}15 \leq \mathrm{X}< \\
25\end{array}$ & Kurang positif \\
\hline 5 & $\mathrm{X}<15$ & Sangat kurang positif \\
\hline
\end{tabular}

Penelitian mengenai respon siswa dianggap berhasil jika jumlah siswa yang memiliki respon positif lebih banyak daripada jumlah siswa yang memiliki respon kurang positif. Dengan kata lain, penelitian dianggap berhasil apabila $75 \%$ dari jumlah siswa memberikan respon positif. Jika hal tersebut dicapai penelitian dapat dihentikan.

Adapun cara mencari skor rata rata respon siswa terhadap penggunaan teknik permainan tebak huruf adalah.

Keterangan

$\mathrm{X}=$ jumlah skor rata rata responden siswa 
$\sum \mathrm{n}=$ jumlah skor siswa

$\mathrm{N}=$ jumlah siswa yang mengisi angket

Skor rata rata ini dijadikan sebagai acuan respon siswa secara klasikal dan hasil ini akan digunakan sebagai refleksi terhadap tindakan selanjutnya

\section{Hasil dan Pembahasan}

Pada hasil pretest, ketuntasan klasikal siswa kelas X4 adalah $0 \%$ dengan rincian nilai sebagai berikut.

Tabel 4 : Frekuensi Nilai Pretest

\begin{tabular}{|l|l|l|l|l|l|}
\hline No & $\begin{array}{l}\text { Interval } \\
\text { Nilai }\end{array}$ & Frekuensi & Kategori & Makna & Persentase \\
\hline 1 & $\begin{array}{l}100- \\
86\end{array}$ & 0 & $\mathrm{~A}$ & $\begin{array}{l}\text { Sangat } \\
\text { Baik }\end{array}$ & $0 \%$ \\
\hline 2 & $\begin{array}{l}85- \\
76\end{array}$ & 0 & $\mathrm{~B}$ & Baik & $0 \%$ \\
\hline 3 & $\begin{array}{l}75- \\
60\end{array}$ & 3 & $\mathrm{C}$ & Cukup & $11,11 \%$ \\
\hline 4 & $59-$ & 15 & $\mathrm{D}$ & Kurang & $55,55 \%$ \\
\hline 5 & $30-0$ & 9 & $\mathrm{E}$ & $\begin{array}{l}\text { Sangat } \\
\text { Kurang }\end{array}$ & $33,33 \%$ \\
\hline
\end{tabular}

Setelah melaksakan posttest I dengan sebelumya sudah menerapkan permainan tebak kata Hiragana dengan menggunakan metode Team Games Tournament (TGT) di dapatkan hasil bahwa 16 orang siswa $(59,25 \%)$ dari 27 siswa yang mengikuti posttest I telah mendapatkan hasil nilai di atas KKM, sedangkan 17 siswa lainnya mendapatkan nilai di bawah KKM namun dari nilai di atas terdapat peningkatan nilai dari seluruh siswa. Nilai tertinggi yang di dapatkan oleh siswa adalah sebesar 100 dan nilai terkecil yang di dapat oleh siswa yaitu sebesar 53,3. Berikut nilai persentase posttest siswa kelas X4.

Tabel 5 : Frekuensi Nilai Posttest I

\begin{tabular}{|l|l|l|l|l|l|}
\hline $\begin{array}{l}\text { N } \\
\text { o }\end{array}$ & $\begin{array}{l}\text { Inter } \\
\text { val } \\
\text { Nilai }\end{array}$ & $\begin{array}{l}\text { Freku } \\
\text { ensi }\end{array}$ & $\begin{array}{l}\text { Kate } \\
\text { gori }\end{array}$ & Makna & $\begin{array}{l}\text { Perse } \\
\text { ntase }\end{array}$ \\
\hline 1 & $\begin{array}{l}100 \\
-86\end{array}$ & 8 & A & $\begin{array}{l}\text { Sangat } \\
\text { Baik }\end{array}$ & $\begin{array}{l}29,62 \\
\%\end{array}$ \\
\hline 2 & $\begin{array}{l}85- \\
76\end{array}$ & 7 & B & Baik & $\begin{array}{l}25,92 \\
\%\end{array}$ \\
\hline 3 & $\begin{array}{l}75- \\
60\end{array}$ & 10 & C & Cukup & $\begin{array}{l}37,03 \\
\%\end{array}$ \\
\hline 4 & $\begin{array}{l}59- \\
40\end{array}$ & 2 & D & Kurang & $7,4 \%$ \\
\hline 5 & $39-$ & 0 & E & $\begin{array}{l}\text { Sangat } \\
\text { Kurang }\end{array}$ & $0 \%$ \\
\hline
\end{tabular}

Jumlah respons yang diberikan oleh siswa terhadap penerapan permainan tebak kata hiragana dengan menggunakan metode Team Games Tournament (TGT) dengan jumlah nilai angket siswa sebesar 1109 dengan rata rata ( $X$ ) yaitu 41 maka dapat disimpulkan bahwa setelah penerapan permainan tebak kata hiragana dengan menggunakan metode Team Games Tournament (TGT) berada pada kategori "positif". 
Setelah melaksakan posttest II dengan sebelumya sudah menerapkan permainan tebak kata hiragana dengan menggunakan metode Team Games Tournament (TGT) didapatkan hasil bahwa 24 orang siswa (88,88\%) dari 27 siswa yang mengikuti posttest II telah mendapatkan hasil nilai di atas KKM, sedangkan 3 siswa lainnya belum mendapatkan nilai di bawah KKM $(11,11 \%)$ namun dari nilai yang terdapat di atas diketahui adanya peningkatan nilai dari siswa. Nilai tertinggi yang didapatkan oleh siswa adalah sebesar 100 dan nilai terkecil yang di dapat oleh siswa yaitu sebesar 66,6. Berikut nilai persentase posttest II siswa kelas X4.

Tabel 6 : Frekuensi Nilai Posttest II

\begin{tabular}{|l|l|l|l|l|l|}
\hline No & $\begin{array}{l}\text { Interval } \\
\text { Nilai }\end{array}$ & Frekuensi & Kategori & Makna & Persentase \\
\hline 1 & $\begin{array}{l}100- \\
86\end{array}$ & 21 & $\mathrm{~A}$ & $\begin{array}{l}\text { Sangat } \\
\text { Baik }\end{array}$ & $77,77 \%$ \\
\hline 2 & $85-$ & 3 & $\mathrm{~B}$ & Baik & $11,11 \%$ \\
\hline 36 & $75-$ & 3 & $\mathrm{C}$ & Cukup & $11,11 \%$ \\
\hline 30 & $59-$ & 0 & $\mathrm{D}$ & Kurang & $0 \%$ \\
\hline 4 & $39-0$ & 0 & $\mathrm{E}$ & $\begin{array}{l}\text { Sangat } \\
\text { Kurang }\end{array}$ & $0 \%$ \\
\hline
\end{tabular}

Siswa mengalami peningkatan nilai dari pelaksanaan pretest, posttest I sampai posttest II. Dari gambar 1 dapat terlihat bahwa perbedaan rentang nilai siswa terjadi pada setiap tes yang dilakukan. Mulai dari pretest siswa dengan rentang nilai terbanyak terdapat pada rentang nilai 40 - 59 yang merupakan bukan rentang nilai standar KKM yang ditetapkan. Kemudian pada posttest siklus I sudah terdapat 15 siswa yang mendapatkan nilai KKM dan 12 orang masih belum mendapatkan KKM. Dan pada posttest II yang dilakukan, siswa mendapatkan hasil yang lebih positif dimana 24 orang siswa sudah mendapatkan nilai di atas standar KKM yang diberikan yaitu 78 . Jadi sesuai kriteria yang ditentukan bahwa hasil penelitian yang dilakukan mulai dari pretest sampai posttest II sudah mampu meningkatkan kemampuan siswa dalam belajar huruf hiragana.

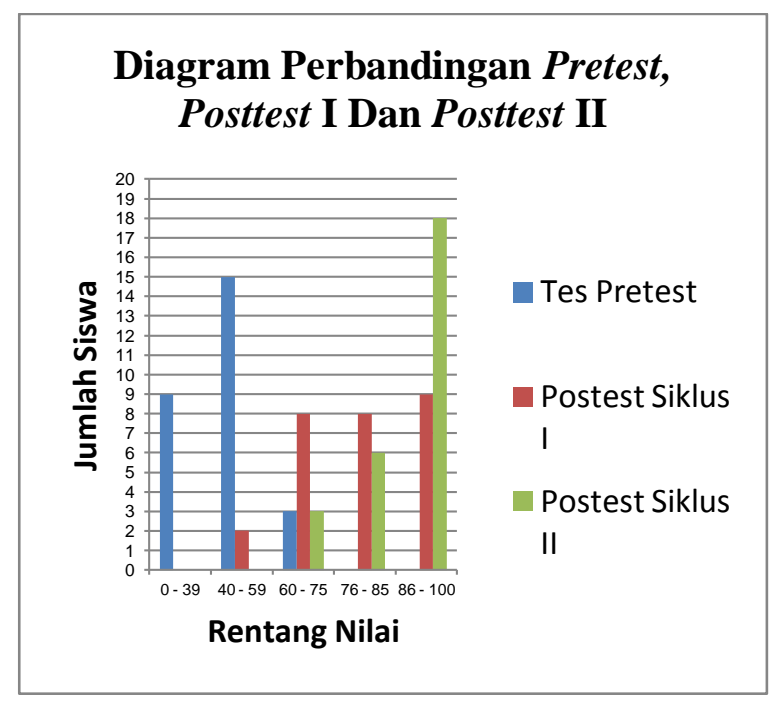

Gambar 1 Diagram Perbandingan Pretest, Posttest I Dan Posttest II

Jumlah respons yang diberikan oleh siswa terhadap penerapan permainan tebak kata hiragana dengan menggunakan metode Team Games Tournament (TGT) pada siklus II dengan jumlah nilai angket siswa sebesar 1238 dengan rata rata ( $X$ ) yaitu 45 dapat 
disimpulkan bahwa setelah penerapan permainan tebak kata hiragana dengan menggunakan metode Team Games Tournament (TGT) berada pada kategori "sangat positif".

\section{Simpulan dan Saran}

HASIL DAN SARAN

Berdasarkan

hasil pembahasan penelitian tindakan kelas yang telah dilaksanakan dalam penerapan permainan tebak kata hiragana dengan menggunakan metode Team Games Tournament (TGT) pada siswa kelas X4 SMA Lab Undiksha Singaraja dapat disimpulkan sebagai berikut.

1.

Penerapan

permainan tebak kata hiragana dengan menggunakan metode Team Games Tournament (TGT) mampu meningkatkan nilai siswa kelas X4 secara signifikan. Hal ini diperoleh dari meningkatnya nilai siswa kelas $\mathrm{X} 4$ setelah penerapan permainan tebak kata hiragana dengan menggunakan metode Team Games Tournament (TGT) di setiap siklusnya. Pada pretest nilai siswa dalam menulis huruf hiragana tidak ada satupun siswa yang mendapatkan nilai di atas standar KKM yang telah ditentukan. Pada siklus I setelah penerapan permainan tebak kata hiragana dengan menggunakan metode Team Games Tournament (TGT) dilaksanakan nilai siswa berangsur baik dimana sebanyak 15 orang siswa atau sebanyak $55,55 \%$ telah mendapatkan nilai diatas KKM yang ditentukan. Kemudian di siklus II siswa yang mendapatkan nilai di atas KKM menjadi 24 orang siswa atau sebesar $88,8 \%$ ini membuktikan bahwa benar kemampuan siswa dalam menulis huruf hiragana telah meningkat setelah adanaya penerapan permainan tebak kata hiragana dengan menggunakan metode Team Games Tournament (TGT).

2.

Penerapan

permainan tebak kata hiragana dengan menggunakan metode Team Games Tournament (TGT) mendapatkan respons yang positif dari siswa kelas X4. Respons positif ini diketahui dari angket yang diberikan pada siswa kelas X4. Pada siklus I dan siklus II, respons positif yang didapatkan melalui angket tertutup dan terbuka. Pada angket tertutup siswa rata rata jawaban sangat setuju pada siklus I adalah $22,59 \%$ dan meningkat menjadi $58,51 \%$ pada siklus II. Pada jawaban setuju pada siklus I $67,4 \%$ pada siklus II menjadi $41,48 \%$. Pada jawaban cukup setuju pada siklus I adalah $10 \%$ kemudian menurun menjadi $0 \%$. Pada jawaban kurang setuju dan sangat tidak setuju di siklus I dan di siklus II tetap dengan persentase $0 \%$. Pada angket terbuka di siklus I sebesar 21 orang siswa tidak memiliki kendala dan tidak mempunyai masukan tertentu selama penerapan permainan tebak kata hiragana dengan menggunakan metode Team Games Tournament (TGT). Di siklus II sebanyak 26 siswa tidak memiliki kendala dan tidak mempunyai masukan tertentu selama penerapan permainan tebak kata hiragana dengan menggunakan metode Team Games Tournament (TGT). Dengan pernyataan ini siswa kelas X4 memberikan respons yang positif dengan adanaya penerapan permainan tebak kata hiragana dengan menggunakan metode Team Games Tournament (TGT).

Berdasarkan penelitian yang telah dilaksanakan, ada beberapa saran yang bisa digunakan sebagai bahan pertimbangan untuk selanjutnya yaitu.

\section{Bagi Guru}

Guru sebaiknya lebih sering menggunakan model pembelajaran yang bervariatif agar siswa tidak bosan, salah satunya adalah permainan tebak kata hiragana dengan menggunakan metode Team Games Tournament (TGT). Guru sebaiknya lebih sering menghimbau siswa untuk belajar dengan penuh semangat sehingga suasana pembelajaran dalam kelas lebih nyaman.

\section{Bagi Siswa}

Dalam mengikuti kegiatan pembelajaran siswa harus lebih aktif untuk bertanya dan mengungkapkan pendapatnya. Siswa sebaiknya lebih semangat dalam mengikuti pembelajaran agar tercipta suasana belajar yang nyaman.

3. Bagi Peneliti Lain 
Dengan adanya penelitian ini diharapkan dapat mengembangkan ide ide kreatif untuk penelitian yang lain dengan mengembangkan media maupun permainan yang menarik menggunakan metode team games tournament (TGT) maupun tebak kata atau metode metode penelitian yang lain agar proses pembelajaran dalam kelas baik pembelajaran bahasa Jepang maupun pembelajaran yang lainnya dapat menjadi lebih menarik siswa dalam mengikuti proses pembelajaran dalam kelas.

\section{Daftar Pustaka}

Fajri. 2011. Implementasi Model Pembelajaran Team Game Tournament (TGT) Untuk Meningkatkan Hasil Belajar Kewirausahaan Siswa Kelas X Busana SMK N 6 Purworejo

http://eprints.ums.ac.id/20879/12/11._NASKAH_PUBLIKASI.pdf.

Hamid. Moh Soleh. 2011. Metode EDU Tainment Menjadikan Siswa Kreatif dan Nyaman di Kelas. Jogjakarta: DIVA Press.

Jogiyanto. 2006. Pembelajaran Metode Kasus Untuk Dosen Dan Mahasiswa. Yogyakarta: Andi Offset.

Muliawan, Ungguh Jasa. 2016. 45 Model Pembelajaran Spektakuler. Yogyakarta: AR-Ruzz Media.

Nurkancana dan Sunartana. 1992. Evaluasi Hasil Belajar. Surabaya. Usaha Nasional.

Partini. 2013. Peningkatan Motivasi Belajar Matematika Tentang Sifat-sifat Bangun Datar Dengan Menggunakan Metode Permainan Tebak Kata Pada Siswa Kelas V SDN 02 Dawung Kecamatan Matesih Kabupaten Karanganyar Tahun Pelajaran 2012/2013

http://eprints.ums.ac.id/23670/13/JURNAL_PUBLIKASI.pdf.

Ratna Dewi Saputri. 2012. Penerapan Metode Tebak Kata untuk Meningkatkan Pemahaman dan Keaktifan Siswa Kelas V Terhadap Mata Pelajaran IPA di Sekolah Dasar Negeri 1 Sawahan Tahun Ajaran 2011/2012. http://eprints.ums.ac.id/19879/12/11._NASKAH_PUBLIKASI.pdf.

Robert E.Slavin. 2010. Cooperative Learning Teori, Riset dan Praktik. Bandung: Penerbit Nusa Media.

Salam, Abdus, dkk. 2015. Effects of Using Teams Games Tournament (TGT) Cooperative Technique for Learning Mathematics in Secondary Schools of Bangladesh.

www.mojet.net/volume3/issue3

Taniredja, T, dkk. 2011. Model-Model Pembelajaran Inovatif. Bandung: Alfabeta.

Trianto. 2010. Mendesain Model Pembelajaran Inovatif-Progresif Konsep, Landasan, dan Implementasinya Pada Kurikulum Tingkat Satuan Satuan Pendidikan (KTSP). Jakarta: Kencana Prenada Media Group. 